\title{
Efficiency Wages, Unemployment, And Labor Discipline
}

Aaron Pacitti, Siena College, USA

\begin{abstract}
This paper explores the economic implications of unemployment by appealing to efficiency wage models. Agency issues in labor markets are first surveyed and discussed, providing the foundation for a detailed analysis and synthesis of two shirking models using uniform language and terminology. The use of a class-based analysis shows that unemployment disciplines both unemployed and employed labor, and explains the presence of unemployment as an equilibrium phenomenon. The economic effects of unemployment on wages, employee effort, labor surveillance, and other aspects, such as unemployment duration, are developed and explored.
\end{abstract}

Keywords: Unemployment; class conflict; efficiency wage; cost of job loss

\section{INTRODUCTION}

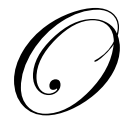

ne of the largest challenges for neoclassical economic theory has been explaining the existence and persistence of unemployment in a competitive capitalist economy. Unlike the market for goods and services, money, and foreign exchange, the labor market does not clear as wages do not to adjust to equilibrate the supply and demand for labor. The labor market is in a constant state of disequilibrium where, paradoxically, unemployment appears to be an equilibrium phenomenon. Why is it, then, that competitive labor market fails to clear in equilibrium?

Marx (1976) viewed unemployment as a central element of capitalism that gives the capitalist class a bargaining power advantage relative to labor. A surplus population of employable labor, constantly in competition for jobs, makes labor a non-scarce good and thus relieves upward pressure on wages. When capitalists can hire labor for a lower wage, it increases the surplus value that can be extracted from labor and thus enables a higher rate of profit. Unemployment, in other words, is rooted in class conflict as it serves to depress wages and ensure profits.

Marx's theory of unemployment is similar to Kalecki (1943), who suggested that full employment would reduce the social and economic power of capital over labor. Despite the ability of full employment policies to increase aggregate demand and thus, potentially, firm profits, Kalecki sees class interests dominating economic interests. Indeed, "'discipline in the factories' and 'political stability' are more appreciated than profits by business leaders" (p. 351). Unemployment thus preserves the existing power relations between capital and labor.

Keynes (1964) argued that labor markets do not clear because money wages are downwardly rigid. Multiterm labor contracts, legislation, and the resistance among workers to accept nominal wage cuts create involuntary unemployment, where unemployed individuals are willing to supply labor at the current market wage yet are unable to find employment as there are no firms willing to hire additional labor at this wage. Given these constraints, the wage that would clear the labor market is either unattainable or infeasible.

Friedman (1968) and Phelps (1968) see unemployment rooted in the microeconomic realm as workers quit their current jobs to rationally search for more attractive positions elsewhere. Unemployment is both voluntary and frictional. Imperfect information regarding job vacancies, wages, search costs, and geographic constraints create the frictions that grind the market-clearing process to a halt. However, in the long run an economy will gravitate towards an equilibrium, or natural rate of unemployment. 
Using an efficiency wage model, Shapiro and Stiglitz (1984) offer a modern neoclassical hypothesis of why wages are downwardly rigid, and thus why the labor market does not clear. An efficiency wage is a wage paid by a firm that is in excess of the competitive level to elicit greater effort from its employees. Since profit-maximizing firms rationally respond to this relationship, each will offer a wage higher than that which would clear the labor market. However, "as all firms raise their wages, their demand for labor decreases, and unemployment results" (p. 433).

Efficiency wage models, however, fail to account for the class issues-as noted by Marx and Kaleckiassociated with unemployment. By appealing to the economic and social implications of efficiency wage models, this paper will highlight the class-biased channels through which unemployment disciplines both unemployed and employed labor. These findings will expand and refine the Marxian theory of unemployment. The models presented by Shapiro and Stiglitz (1984) and Bowles (1985) will serve as the springboard for this analysis. By focusing on the disciplining devices that are used to mitigate the principal-agent problem in labor markets, four novel class-based perspectives on the economic and social functions of unemployment will be discussed.

The remainder of this paper is organized as follows: Section 2 briefly examines the social composition of the labor market and discusses efficiency wage theory. Section 3 presents a detailed analysis using of the models developed by Shapiro and Stiglitz (1984) and Bowles (1985) and highlights their similarities using uniform language and notation. Section 4 applies the findings from section 3 to a Marxian theory of unemployment and develops and presents four disciplinary functions of unemployment. Section 5 summarizes the main findings and concludes.

\section{LABOR MARKETS AND EFFICIENCY WAGES}

Unlike the market for goods, money, and foreign exchange, the labor market is largely governed by a set of social relations that are largely absent from these other markets. For example, human beings and their labor power are the goods purchased and sold in labor markets and there is stochastic variability in their abilities, preferences, and behavior, which is usually unobservable to anyone but the worker. In other words, labor is not a homogenous good (Solow 1980, p. 4). This is not the case with other goods or markets. For example, apples do not care in which grocer they are sold and by whom they are eaten and they do not get depressed if they grow old, rot, and are discarded. ${ }^{1}$ Workers, however, do care where they perform their services and do care how their services are used. Certain people might choose to work with employers who have a mission or norms similar to their own. Some workers may prefer to only work in certain locales, even if wages are higher elsewhere. Others might trade off job quality for a higher salary. Moreover, if an individual is laid off or cannot find employment at all, there are serious economic and social costs associated with unemployment (Wisman 2010; Mazerolle and Singh, 2004).

The labor market is also governed by sociological and psychological principles-habit, custom, fairness, altruism, deception, and malfeasance - that might guide actions more so than pure economic rationality (Akerlof 1982, 1984). This requires an analysis of labor market performance to include sociological as well as economic motives. Indeed, Solow (1980) suggests that "the objectives of the participants [in labor markets] are not always the ones we normally impute to economic agents," and that "social conventions, or principles of appropriate behavior, whose source is not entirely individualistic" must be taken into account (p. 3).

Finally, exchanges in labor markets are "contested" as the parties to the transaction have conflicting interests. $^{2}$ The principal-agent problem results from the fact that the "terms arising from exchange are not generally enforceable at zero cost to exchanging parties" and "the benefit the parties derive from the transaction depends on their own capacities to enforce competing claims" (Bowles and Gintis 1993, p. 85). This gives rise to power relations between transacting individuals.

\footnotetext{
${ }^{1}$ Solow (1980) highlighted the centrality of labor market performance in his presidential address to the American Economic Association because it "connects quickly with everything else in the economy and its performance matters more directly for most people than that of any other market. Moreover, the labor market's own special pathology, unemployment, is particularly visible, particularly unsettling, and particularly frustrating" (p. 2).

${ }^{2}$ Of course conflicting interests are present in nearly every market between buyer and seller. However, it will soon be shown that this conflict is particularly acute in labor market transactions.
} 
One of the main mechanisms used to enforce competing claims in the labor market is an efficiency wage. The concept of an efficiency wage is hardly new-its origins can be traced to Adam Smith (1976) ${ }^{3}$ and Alfred Marshall (1920). ${ }^{4}$ However, modern economic theory has refined and expanded this concept significantly. Yet this development and expansion has proceeded without developing an analysis of the class-based results that stem from this theory. Instead, the theory is framed in terms of asymmetric information, agency issues, and incentive effects. These issues require that firms employ supervisory labor or pay an above-market wage to reduce shirking. This study will focus on the latter technique.

The main assumption in efficiency wage models is that productivity and effort—work quality, broadly — are positively related to the wage rate. Lower wages will induce lower quality work and less effort expended by the worker, and conversely for higher wages. By paying an efficiency wage, firms can maximize their profits by minimizing their effective total labor costs. ${ }^{5}$ When applied to an analysis of the labor market, efficiency wage models predict that "firms may not lower their wages, even in the face of unemployment, if net productivity depends on wages" (Shapiro and Stiglitz 1985, p. 1215) or if "the wage enters the production function in a labor augmenting way" (Solow 1979, p. 81). Efficiency wage models can thus explain the Keynesian notion of sticky wages and account for involuntary unemployment in equilibrium, but proponents of these models do not extend their findings to the sociological domain by discussing the class- and power-based implications of efficiency wages.

Incentive or shirking models of unemployment offer a springboard for including an economic analysis of class using the efficiency wage framework. Shirking models stipulate that if any worker is detected providing an unacceptably low level of effort he will be fired. ${ }^{6}$ This provides workers with an incentive not to shirk because employers have the "capacity to gain compliance by the privately wielded threat of imposing sanctions" (Bowles and Gintis 1990, p. 293). One such sanction could be financial because any employee paid an efficiency wage is better off than his next best alternative. The difference between the efficiency wage and the level of income an employee would receive were he to become unemployed is called the enforcement rent (or the cost of job loss), which "is used by [the employer] to enforce claims against [the employee] when [the labor contract is] not thirdparty enforceable" (Bowles and Gintis 2000, p. 1421). The possibility of becoming unemployed, with its associated costs, disciplines workers to provide a level of effort that is acceptable to the firm.

\footnotetext{
${ }^{3}$ Smith (1976) noted:

The liberal reward of labor...increases the industry of the common people. The wages of labor are the encouragement of industry, which, like every other human quality, improves in proportion to the encouragement it receives. A plentiful subsistence increases the bodily strength of the laborer, and the comfortable hope of bettering his condition, and of ending his days perhaps in ease and plenty, animates him to exert that strength to the utmost. Where wages are high, accordingly, we shall always find the workmen more active, diligent, and expeditious, than where they are low... (p. 91)

${ }^{4}$ Marshall (1920) coined the term "efficiency wage" in discussing different types of remuneration:

...efficiency wages, or more broadly efficiency-earnings; that is, earnings measured, not as time-earnings are with reference to the time spent in earning them; and not as piece-work earnings are with reference to the amount of output resulting from the work by which they are earned; but with reference to the exertion of ability and efficiency required of the worker. (p. 456, emphasis in original)

5 Effective labor costs are defined as the total wage bill divided by the product of the number of workers multiplied by their efficiency units, where normal efficiency is equal to unity. Workers who are more productive than average have an efficiency coefficient greater than unity, and workers operating below normal efficiency standards have a coefficient less than unity. Therefore, increases in worker productivity correlate to lower effective labor costs. This, too, was noted by Marshall (1920):

For we have hitherto supposed that it is a matter of indifference to the employer whether he employs few or many people to do a piece of work, provided his total wages-bill for the work is the same. But this is not the case. Those workers who earn most in a week when paid at a given rate for their work, are those who are cheapest to their employers...For they use only the same amount of fixed capital as their slower fellow-workers; and, since they turn out more work, each part of it has to bear a less charge on this account. The prime costs are equal in the two cases; but the total cost of that done by those who are more efficient, and get the higher time-wages, is lower than the total cost of that done by those who get the lower time-wages at the same rate of piece-work payment. (p. 457)

${ }^{6}$ These models assume, incorrectly, that there are no costs to firing or hiring an employee. Training new hires, for example, especially if the job requires a significant amount of firm-specific human capital, would result in temporarily lower output, and thus foregone revenues, in addition to the cost of training resources.
} 
In addition to the effort-inducing effect of high wages, the threat of contract termination (i.e., unemployment) further disciplines workers. This is a profit-maximizing strategy because the "threat of termination encourages behavior that the principal...finds desirable while avoiding some of the negative sorting effects that could result from penalizing agents...through changes in the terms of the contract" (Stiglitz and Weiss 1983, p. 912). Firms rationally choose to make quantity adjustments instead of price adjustments, which explains the use of layoffs instead of wage cuts given a reduction in aggregate demand. Adverse selection and moral hazard effects would accompany a wage decrease for all workers, whereas layoffs only affect a small percentage of the firm's labor force. $^{7}$

The main conclusion to be drawn from efficiency wage models of the labor market is that rational, profitmaximizing firms pay a wage that is higher than the competitive level. This discourages employees from shirking and incentivizes them to supply greater levels of on-the-job effort. However, many of these models ignore the classbiased dimensions of their results. ${ }^{8}$ That is, they do not extend their analysis to investigate how efficiency wages create class conflict and thus affect the social relationship between labor and capital. In order to highlight these effects, it is necessary to introduce a framework from which these relationships will be analyzed.

\section{UNIFORM ANALYSIS OF TWO SHIRKING MODELS}

This section analyzes two related shirking models of unemployment: Shapiro and Stiglitz (1984) and Bowles (1985) each present a model arguing that unemployment serves as a worker discipline device and explaining involuntary unemployment as an equilibrium phenomenon. Each introduces a novel conception of a firm's optimal wage strategy, which is structured to minimize shirking. By selecting and presenting only the critical elements of each model and discussing them in a uniform language, this analysis will summarize the disciplining devices available to an employer.

\subsection{Shapiro and Stiglitz's Model and the No-Shirking Condition}

Shapiro and Stiglitz (1984) use a utility maximizing framework to "show how the information structure of employer-employee relationships, in particular the inability of employers to costlessly observe workers' on-the-job effort, can explain involuntary unemployment" (p. 433). ${ }^{9}$ Moreover, "imperfect monitoring necessitates unemployment in equilibrium" (p. 433, emphasis added), and this level of unemployment is consistent with labor market equilibrium if firms pay an efficiency wage. Shapiro and Stiglitz derive a "no-shirking condition" (NSC) from the utility functions of employed shirkers, employed non-shirkers, and the unemployed. Workers will choose not to shirk when the utility of being an employed non-shirker is greater than or equal to the utility associated with being an employed shirker. It is necessary to assume that the utility of an unemployed worker is less than the utility of an employed worker, regardless of whether or not he shirks. The NSC, which relates the critical, or efficiency, wage the firm must pay to induce non-shirking behavior $(w)$ to a set of independent variables takes the form:

$w \geq \bar{w}+e+(e / q)(a+b+r)$

Six relationships can be seen in equation (1). First, $w$ is positively related to the level of unemployment benefits $(\bar{w})$, such as unemployment insurance or food stamps. With a high level of unemployment benefits, a worker's utility while unemployed is increased, which decreases the penalty associated with unemployment and therefore encourages on-the-job shirking. ${ }^{10}$ This "highlights the basic implication of the NSC: unless there is a penalty associated with being unemployed, everyone will shirk" (p. 436). To prevent shirking, the firm must pay a higher wage to increase the unemployment penalty.

\footnotetext{
${ }^{7}$ In fact, "if a firm facing an excess supply of workers were to cut its wages, the response of its workers would be so adverse as to outweigh the direct gains to the firm from the lower cost per worker" (Weiss 1990, p. 55).

${ }^{8}$ The models and framework developed by Bowles (1985) and Bowles and Gintis (1993) are two exceptions.

${ }^{9}$ Unemployment in these models is purely involuntary as workers have perfect information about available jobs. Search or frictional unemployment does not exist.

${ }^{10}$ The penalty in becoming unemployed is the utility derived from being an employed worker (shirker or non-shirker) less the utility derived from being unemployed.
} 
Second, $w$ is positively related to effort $(e)$. Jobs that require more effort will have to pay a higher wage in order to provide the appropriate financial incentive for the employee to actually work (since effort enters negatively in the worker's utility function).

Third, $w$ is negatively related to the probability of being detected shirking $(q)$, which is a function of the monitoring strategies employed by the firm. When the possibility of being caught shirking increases because of increased monitoring efforts, firms can lower wages.

Fourth, $w$ is positively related to the acquisition rate $(a)$, or "flows out of unemployment" (p. 438). As firms increase their hiring out of the unemployment pool, unemployment duration decreases. This mitigates the unemployment penalty, and firms must pay higher wages to offset this lower penalty.

Fifth, $w$ is positively related to the quit rate $(b)$. As Shapiro and Stiglitz say, "if one is going to have to leave the firm anyway, one might as well cheat on the firm" by shirking (p. 436). Firms that have a large number of quits can pay higher wages to reduce turnover.

Finally, $w$ is positively related to the interest rate $(r)$. When interest rates are high, workers place a greater weight on "the short-run gains from shirking (until one is caught) compared to the losses incurred when one is eventually caught" (p. 436). To counteract this, firms must offer higher wages to discourage shirking.

Furthermore, the determinants of the job acquisition rate can be specified in terms of flows into unemployment and the aggregate level of employment. The following aggregate NSC, similar to equation (1), includes the unemployment rate $(u)$ as a parameter.

$w \geq e+\bar{w}+(e / q)(b / u+r)$

In equation (2), it can be seen that the unemployment rate is negatively related to the efficiency wage. This is the main finding of Shapiro and Stiglitz's model: that "no shirking is inconsistent with full employment" (p. 438, emphasis in original). At full employment, there would be no penalty associated with becoming unemployed as workers who were fired for shirking could immediately obtain a new job. ${ }^{11}$ Involuntary unemployment must exist to prevent on-the-job shirking.

\subsection{Bowles' Model and the Cost of Job Loss}

Much like Shapiro and Stiglitz, Bowles (1985) argues that unemployment has costs and that these costs are necessary to induce workers to act in the interests of their employer. Indeed, financial costs associated with unemployment - what Bowles calls the cost of job loss - play a critical role in his analysis as they force rational, risk-neutral workers to exert effort. The cost of job loss is the employee's fallback position and is defined as the difference between a workers' current wage and the sum of "income-replacing social welfare benefits" and the expected reemployment wage adjusted for the expected length of unemployment (Schor and Bowles 1987, p. 585). In Bowles' (1985) model, similar to the NSC presented in equation (2), the efficiency wage is set to extract effort from workers; the higher the wage, the more effort a worker is likely to expend. The cost of job loss is mathematically expressed as:

$z=w-\left[q \bar{w}+(1-q) w^{r}\right]$

Bowles argues that wages, surveillance inputs (which increase the probability of being detected shirking), and the cost of job loss are positively related to a worker's on-the-job effort. Shirking can be discouraged if a firm increases the cost of job loss $(z)$ by paying higher wages $(w)$ or by increasing the probability of job loss $(q)$ through greater surveillance inputs. The probability of job loss can also be thought of as the expected duration of

\footnotetext{
${ }^{11}$ Kalecki (1943) argues, much like Shapiro and Stiglitz, that full employment policies will be resisted by capital because "[unemployment] would cease to play its role as a disciplinary measure" in the production process (p. 351).
} 
unemployment, expressed as a percentage of one year. Additionally, the cost of job loss can be increased by lower unemployment benefits $(\bar{w})$ or lower re-employment wages $\left(w^{r}\right)$.

In order to compare the cost of job loss to the NSC - that is, to compare Bowles' model to that of Shapiro and Stiglitz, respectively — equation (3) must be solved for the wage $(w)$ that is required to prevent shirking. This yields:

$w \geq z+q\left(\bar{w}-w^{r}\right)+w^{r}$

Four relationships in equation (4) are now made explicit, many of them similar to those found by Shapiro and Stiglitz (1984). First, the efficiency wage $(w)$ is positively related to the cost of job loss $(z)$. As firms pay a higher wage, the financial penalty associated with unemployment increases.

Second, $w$ is negatively related to the probability of job loss or unemployment duration $(q)$. This relationship, however, rests on the assumption that the wage a worker can expect to receive if rehired (the reemployment wage) must exceed the level of income while unemployed $\left(w^{r}>\bar{w}\right)$. Otherwise unemployed workers would stop looking for jobs, choose not to work, and collect unemployment benefits instead. Bowles assumes, given competitive conditions, that the reemployment wage is equal to the current wage $\left(w^{r}=w\right)$. Combining these two assumptions gives $w>\bar{w}$. Therefore, the wage paid by employers must exceed a worker's expected unemployment income for the probability of job loss to be negatively related to the efficiency wage.

Third, $w$ is positively related to unemployment income $(\bar{w})$. The logic here is identical to that from the discussion of Shapiro and Stiglitz's NSC - that with generous unemployment benefits, a worker's utility while unemployed is increased, which decreases the penalty associated with unemployment. Firms must pay higher wages to increase the costs of unemployment.

Finally, $w$ is positively related to the expected reemployment wage $\left(w^{r}\right)$. Dropping the assumption that the reemployment wage is equal to the current wage, if workers can find new employment at a wage that is greater than their current wage, the cost unemployment inflicts upon them diminishes, and so too will the quantity of effort they expend at their current job. To maintain high effort levels, the efficiency wage must increase as expected reemployment income increases.

The key implications of Bowles' cost of job loss is identical to that derived from Shapiro and Stiglitz's NSC: unemployment must impose a financial penalty on workers if they are to supply on-the-job effort and full employment is incompatible with no-shirking behavior. Although the unemployment rate is not explicitly included in the calculation of the cost of job loss, the payment of a no-shirking wage causes involuntary unemployment in equilibrium as wages are in excess of that which would clear the labor market. ${ }^{12}$

\section{ECONOMIC EFFECTS AND DISCIPLINARY FUNCTIONS OF UNEMPLOYMENT}

This section will apply the findings from section 3 to a class-based analysis of unemployment. Four functions of unemployment will be presented, each serving to augment and refine the Marxian theory of unemployment. The main finding is that the costs arising from the existence of unemployment are not just imposed upon unemployed labor, but employed labor as well. A more complete, and significantly more severe, conception of unemployment emerges - one that exposes unemployment as a distinctly class-biased feature of a competitive capitalist economy. Indeed, the relationship between unemployment and class conflict is far greater than that suggested by a traditional Marxian theory of unemployment.

\footnotetext{
${ }^{12}$ As Bowles (1985) says, "the wage rate offered by the competitive profit-maximizing employer will exceed the worker's next best alternative," and, therefore, "labor market competition cannot clear the labor market." In other words, "market clearing- the absence of involuntary unemployment-implies labor market disequilibrium" (p. 26).
} 


\subsection{Unemployment and Wages}

The main tenet of the Marxian theory of unemployment is that the size of the reserve army is inversely related to the wage rate. Marx (1976) argues that "the general movements of wages are exclusively regulated by the expansion and contraction of the industrial reserve army" (p. 790, emphasis added). This is the law of supply and demand: as supply increases (unemployed labor), wages will fall. Employed workers will also find themselves in a disadvantaged bargaining position with high unemployment rates, because attempts to secure higher wages through strikes or unionization would rarely succeed in an environment where firms can fire militant workers and replace them with hungry, docile workers from the reserve army. In either case, unemployment and wages are negatively related.

Efficiency wage models arrive at the same conclusion, but for reasons altogether different than those suggested by Marx. A rise in the unemployment rate increases the penalty associated with being unemployed (in terms of a greater probability of job loss and the duration of unemployment) and, recalling from equation (2), the unemployment rate and the wage necessary to prevent shirking are inversely related. This allows capitalists to pay a lower wage than they would if unemployment was low. So as unemployment increases, wages will fall, but not for the supply and demand reasons that Marx stipulated. Unemployment serves as a substitute for the enforcement rent - the difference between the no-shirking wage and the worker's next best alternative, even if that alternative is unemployment income. Efficiency wage theory thus strengthens Marx's conclusion that unemployment will lead to lower wages, albeit through a different channel.

\subsection{Unemployment and Employee Effort}

Efficiency wage literature argues that quality, not just quantity, depends on price. Therefore, wages are also a function of the quality of labor, or effort. From the unemployment-wage relationship described in section 3, the Marxian theory of unemployment can be augmented to show how employee effort is related to the unemployment rate: the existence of unemployment and the financial costs associated with it, namely the cost of job loss, force employed workers to supply more effort for a given wage. hypothesized:

Marx (1976) only offered a brief treatment of the relationship between unemployment and effort. He

The over-work of the employed part of the working class swells the ranks of its reserve, while, conversely, the greater pressure that the reserve by its competition exerts on the employed workers forces them to submit to overwork and subjects them to the dictates of capital. The condemnation of one part of the working class to enforced idleness by the over-work of the other part, and vice versa, becomes a means of enriching the individual capitalists... (p. 789)

Here Marx highlights an ambiguous relationship between unemployment and effort ("over-work"). He first suggests that increased effort among the employed increases unemployment, effectively assuming the "lump of labor" fallacy. Then he suggests the opposite direction of causation - that unemployment disciplines employed workers by forcing them to supply more effort, else they be fired for shirking - which is the argument put forth by efficiency wage theory. Perhaps both effects could be operational, but Marx fails to distinguish which effect dominates. Later he reiterates the second hypothesis when he states that "the pressure of the unemployed compels those who are employed to furnish more labor" (p. 793). It is clear that Marx had a conception of the relationship between unemployment and effort, but he does not fully establish a convincing direction of causation. Applying the findings from section 3 helps resolve the ambiguity in Marx's analysis by suggesting that his second hypothesis is correct: unemployment allows the firm to extract more effort from employed labor for a given wage. 


\subsection{Unemployment and Labor Surveillance}

Another class-biased function of unemployment concerns the role of employee monitoring. ${ }^{13}$ In addition to paying an efficiency wage, firms can also employ monitoring techniques to ensure that workers are not shirking. Thus there is a positive relationship between the amount of supervision inputs and the amount of effort exerted, and the increased use of monitoring technology reduces the bargaining power of labor (Skott and Guy 2007). However, both higher wages and increased monitoring inputs are costly for the firm. The existence of unemployment thus serves as a mitigating factor in incurring these effort-extraction costs.

The probability of becoming unemployed, which varies directly with the unemployment rate, can temper the need to pay higher wages to induce effort. The same relationship holds between unemployment and labor surveillance: increases in unemployment serve as a substitute for supervisory labor and monitoring technology, which was proxied by $q$ in the analysis in section 3 . As the threat of unemployment rises, or as the unemployment rate increases, firms can extract greater effort from their employees without incurring additional wage or surveillance costs. Unemployed labor effectively subsidizes capital as a greater rate of unemployment allows capital to decrease or hold constant the quantity of monitoring inputs. Unemployment functions not only to keep wages low and effort high, which are both direct costs to workers, but also to alleviate the need for costly monitoring inputs, which is a direct benefit for capital.

\subsection{Other Dimensions of Unemployment}

The cost of job loss is partially determined by unemployment duration, or the probability of job loss; income-replacing social welfare payments; and reemployment wages. Assuming, for whatever reason, that the unemployment rate were to remain fixed over a span of time, capital still has the tools necessary to depress wages, extract greater effort, reduce the need for monitoring inputs, and decrease labor's bargaining power more broadly. This will be true, although to a lesser extent, if the unemployment rate is held fixed at very low levels (Pacitti 2010). ${ }^{14}$ The cost of job loss, from equation (3), measures different dimensions of an unemployment spell and suggests alternative routes capital can take to exert its economic and social dominance over labor.

For a fixed rate of unemployment, a longer duration of unemployment will, ceteris paribus, lead to an increase in the penalty associated with being fired. Capital cannot directly control the average length of unemployment, but they could implement biased technological changes that would render the skills of unemployed labor obsolete and thus make them less likely to be rehired. ${ }^{15}$ This would indirectly affect the mean unemployment duration by increasing the friction unemployed workers must face when searching for new employment opportunities.

Capital could also marshal its political resources to decrease the level of social welfare programs. Decreasing benefits to unemployed workers will, for a given level of unemployment, increase the cost associated with becoming unemployed. This will allow capital to pay lower wages, extract greater levels of employee effort, and reduce monitoring inputs.

For reemployed workers, the aggregate shift to from high-wage, primary labor market employment to lowwage service-sector employment has had the effect of lowering reemployment wages and increasing permanent

\footnotetext{
${ }^{13}$ Examples of monitoring techniques include increasing the quantity of supervisory labor and the use of surveillance equipment, such as keystroke logging, internet monitoring, surveillance cameras, and GPS tracking devices.

${ }^{14}$ For example, the unemployment rate in the United States during the 1990s expansion was low by historical standards. However, labor was not able to translate this advantageous bargaining position into higher wages because different dimensions of unemployment changed adversely. Both the mean and median duration of unemployment rose, the probability of job loss increased (although not for the entire expansion), and alternate sources of income dropped dramatically. The latter event was the result of an increasing incidence of part-time employment arrangements, a shift from welfare to "workfare," and the decline in the percentage of the workforce belonging to a union.

${ }^{15}$ Although Marx (1976) was not referring specifically to technology's effect on unemployment duration, he did note the classbiased nature of technological change: "It would be possible to write a whole history of the inventions made since 1830 for the sole purpose of providing capital with weapons against working-class revolt" (p. 563).
} 
income losses due to displacement (Couch and Placzek 2010; Farber 1997, 2005). Additionally, the deskilling of the labor process through technological change could reduce reemployment wages. ${ }^{16}$ Workers who do not have access to well-funded job placement or retraining programs are likely to experience depreciation in their stock of human capital. This limits the range of reemployment opportunities and increases employment insecurity, in addition to introducing destabilizing social factors like depression, divorce, stress, and income uncertainty (Wisman 2010; Mazerolle and Singh, 2004).

\section{SUMMARY AND CONCLUSION}

This paper developed and identified four disciplinary functions of unemployment through an analysis and synthesis of the efficiency wage models presented by Shapiro and Stiglitz (1984) and Bowles (1985). Unemployment, it is argued, imposes upon both unemployed and employed workers and that these costs have significant economic effects on wages, employee effort, labor surveillance, in addition to other dimensions of unemployment, such as unemployment duration. Although well-beyond the scope of the current study, the exploration of resolution mechanisms to the class-biased nature of unemployment and agency issues - such as targeted government intervention in labor markets, redistributive schemes, and more progressive labor market policy—represent worthy areas of research for policy makers and economists alike.

\section{AUTHOR INFORMATION}

Aaron Pacitti is Assistant Professor of Economics at Siena College, Loudonville, NY. His research interests are macroeconomics and political economy. His current research projects include the economic effects of employment insecurity, the social bargain, and the costs of job loss; the measurement of employee effort; and the causes of jobless recoveries.

\section{REFERENCES}

1. Akerlof, George A. (1982). "Labor Contracts as Partial Gift Exchange." Quarterly Journal of Economics, 97 (4): 543-569.

2. . (1984). "Gift Exchange and Efficiency-Wage Theory: Four Views." American Economic Review, $74(2): 79-83$.

3. Bowles, Samuel. (1985). "The Production Process in a Competitive Economy: Walrasian, Neo-Hobbesian, and Marxian Models." American Economic Review, 75 (1): 16-36.

4. (1986). "The Production Process in a Competitive Economy: Reply." American Economic Review, 76 (5): 1203-1204.

5. Bowles, Samuel and Herbert Gintis. (1990a). "Contested Exchange: New Microfoundations for the Political Economy of Capitalism." Politics \& Society, 18 (2): 165-222.

$6 . \quad$ _. (1993). "The Revenge of Homo Economicus: Contested Exchange and the Revival of Political Economy." Journal of Economic Perspectives, 7 (1): 83-102.

7. . (2000). "Walrasian Economics in Retrospect." Quarterly Journal of Economics, 115 (4): 14111439.

8. Couch, Kenneth and Dana W. Placzek. (2010). "Earnings Losses of Displaced Workers Revisited.” American Economic Review, 100 (1): 572-589.

9. $\quad$ Farber, Henry S. (1997). "The Changing Face of Job Loss in the United States, 1981-1995." Brookings Papers on Economic Activity (1997): 55-142.

10. _ (2005). "What Do We Know About Job Loss in the United States? Evidence from the Displaced Workers Survey, 1984-2004.” Working Paper 498, Princeton University.

11. Friedman, Milton. (1968). "The Role of Monetary Policy.” American Economic Review, 58 (1): 1-17.

12. Kalecki, Michal. (1943). "Political Aspects of Full Employment." Political Quarterly, 14 (4): 322-331.

\footnotetext{
${ }^{16}$ In 1996, Alan Greenspan hypothesized to colleagues at the Fed about the "traumatized worker"- someone who felt job insecurity in the changing economy and so was accepting smaller wage increases. He had talked to business leaders who said their workers were not agitating and were fearful that their skills might not be marketable if they were forced to change jobs (Woodward, 2000 p. 168, emphasis added).
} 
13. Keynes, John Maynard. (1964). The General Theory of Employment, Interest, and Money. San Diego: Harcourt Brace.

14. Marshall, Alfred. (1920). Principles of Economics. Eighth Edition. London: Macmillan.

15. Marx, Karl. (1976). Capital, Vol. 1. Harmondsworth: Penguin.

16. Mazerolle, Maurice J. and Gangaram Singh. (2004). "Economic and Social Correlates of Re-Employment Following Job Displacement: Evidence from 21 Plant Closures in Ontario.” American Journal of Economics and Sociology, 63 (3): 717-730.

17. Pacitti, Aaron. (2010). "Labor Market Institutions, the Cost of Job Loss, and the Phillips Curve." Working Paper 7, Siena College.

18. Phelps, Edmund S. (1968). "Money Wage Dynamics and Labor Market Equilibrium." Journal of Political Economy, 76 (4), Part 2: 678-711.

19. Schor, Juliet B. and Samuel Bowles. (1987). "Employment Rents and the Incidence of Strikes." Review of Economic Studies 69 (4): 584-92.

20. Shapiro, Carl and Joseph Stiglitz. (1984). "Equilibrium Unemployment as a Worker Discipline Device." American Economic Review, 74 (3): 433-444.

21. _ _ (1985). "Can Unemployment Be Involuntary? Reply.” American Economic Review, 75 (5): 1215 1217.

22. Skott, Peter and Frederick Guy. (2007). “A Model of Power-Biased Technical Change.” Economic Letters, 95 (2007): 124-131.

23. Solow, Robert. (1979). "Another Possible Source of Wage Stickiness.” Journal of Macroeconomics, 1 (1): 79-82.

24. Solow, Robert. (1980). “On Theories of Unemployment.” American Economic Review, 70 (1): 1-11.

25. Stiglitz, Joseph E. and Andrew Weiss. (1983). "Incentive Effects of Terminations: Applications to the Credit and Labor Markets." American Economic Review, 73 (5): 912-927.

26. Smith, Adam. (1976). The Wealth of Nations. Chicago: University of Chicago Press.

27. Weiss, Andrew. (1990). Efficiency Wages. Princeton: Princeton University Press.

28. Wisman, Jon D. (2010). "The Moral Imperative and Social Rationality of Government-Guaranteed Employment and Reskilling." Review of Social Economy, 68 (1): 35-67.

29. Woodward, Bob. (2000). Maestro: Greenspan's Fed and the American Boom. New York: Simon and Schuster. 